\title{
Alberto Limentani - Marco Infurna, L'epica romanza nel Medioevo
}

\section{Walter Meliga}

\section{Q OpenEdition}

1 Journals

\section{Edizione digitale}

URL: http://journals.openedition.org/studifrancesi/7459

DOI: $10.4000 /$ studifrancesi.7459

ISSN: 2421-5856

\section{Editore}

Rosenberg \& Sellier

\section{Edizione cartacea}

Data di pubblicazione: 1 décembre 2009

Paginazione: 598-599

ISSN: 0039-2944

\section{Notizia bibliografica digitale}

Walter Meliga, «Alberto Limentani - Marco Infurna, L'epica romanza nel Medioevo», Studi Francesi

[Online], 159 (LIII | III) | 2009, online dal 30 novembre 2015, consultato il 08 janvier 2021. URL: http:// journals.openedition.org/studifrancesi/7459; DOI: https://doi.org/10.4000/studifrancesi.7459

Questo documento è stato generato automaticamente il 8 janvier 2021.

\section{(c) (i) (9)}

Studi Francesi è distribuita con Licenza Creative Commons Attribuzione - Non commerciale - Non opere derivate 4.0 Internazionale. 


\title{
Alberto Limentani - Marco Infurna, L'epica romanza nel Medioevo
}

\author{
Walter Meliga
}

NOTIZIA

ALBERTO LIMENTANI - MARCO INFURNA, L'epica romanza nel Medioevo, Bologna, Il Mulino, 2007 («Introduzioni»), pp. 100.

1 Riedizione in volumetto autonomo, e con modifiche e aggiornamenti bibliografici, del capitolo «L'epica» in La letteratura romanza medievale. Una storia per generi, a cura di Costanzo Di Girolamo, Bologna, Il Mulino, 1994, pp. 19-62, 363-373.

2 Il lavoro resta una buona e agile introduzione all'epica romanza, utile nella didattica universitaria. 